\title{
Locally Aggressive De Novo Spinal Fibromatosis: Case Report and Review of the Literature
}

\author{
Lokal Agresif Seyirli De Novo Omurga Fibromatozisi: Olgu Sunumu ve \\ Literatürün Gözden Geçirilmesi
}

Murat Sakir EKSI ${ }^{1}$, Huseyin Kemal TURKOZ ${ }^{2}$, Emel Ece OZCAN EKSI ${ }^{1}$, Akin AKAKIN ${ }^{3}$, Zafer Orkun TOKTAS ${ }^{3}$, Deniz KONYA ${ }^{3}$

${ }^{1}$ University of California, Department of Orthopedic Surgery-Spine Center, San Francisco, CA, USA

${ }^{2}$ Marmara University, School of Medicine, Department of Pathology, Istanbul, Turkey

${ }^{3}$ Bahcesehir University, School of Medicine, Department of Neurosurgery, Istanbul, Turkey

Corresponding Author: Murat Sakir EKSI / E-mail: muratsakireksi@gmail.com and EksiM@orthosurg.ucsf.edu

\begin{abstract}
Fibromatosis is a benign lesion, which originates from proliferating fibroblasts. Although fibromatosis is a benign tumor, it is locally aggressive and invasive. Spinal presentation of fibromatosis is very rare, and case reports are the only source of the clinical knowledge. Herein, we describe the oldest patient having spinal fibromatosis with de novo occurrence and aggressive nature. A 68-year-old female patient admitted to our outpatient clinic with low back pain and neurological claudication. On lumbar spine magnetic resonance imaging, she had spinal canal stenosis with a concomitant lesion in the left longissimus muscle. We did our best to resect the tumor, entirely. The pathology result was consistent with spindle cell lesion. The lesion recurred 6 months after the primary surgery. In the second surgery, we did en bloc resection. Pathology and immunohistochemical analysis results were consistent with fibromatosis. After the second surgery, she had adjuvant radiotherapy. There was nothing other than radionecrosis in the operation site, still after 2 years. In conclusion, radiological work-up is usually insufficient to make fibromatosis diagnosis and whole pathological specimen should be carefully evaluated to achieve the accurate diagnosis. Spinal fibromatosis is very rare and its treatment methods have not universally been conceptualized. However, adjuvant therapies are necessary after en bloc resection.
\end{abstract}

KEYWORDS: Fibromatosis, Lumbar spine, Radiotherapy, Surgery

öz

Fibromatozis, fibroblastların çoğalması sonrası oluşan bening bir lezyondur. Fibromatozis, bening olmasına rağmen, lokal olarak agresifdir ve invazif bir seyir seyreder. Spinal fibromatozis çok nadirdir ve literatürde sadece olgu sunumları bulunmaktadır. Yazıda, de novo oluşan ve agresif bir klinik tabloya sahip olan, literatürdeki en yaşı hasta sunuldu. Altmış sekiz yaşında kadın bir hasta kliniğimize bel ağrısı ve nörojenik kladikasyon ile başvurdu. Lomber MR incelemesinde, spinal dar kanal ile beraber, sol paraspinal alanda, longissimus kasının içinde kitle lezyonu saptandı. Mümkün olan en geniş cerrahi eksizyon uygulandı. Patoloji sonucu iğsi hücreli lezyon olarak geldi. Altı ay sonra, lezyon nüksetti. İkinci ameliyatta, en blok rezeksiyon yapıldı. Patoloji ve immünohistokimyasal çalışmalar patolojiyi fibromatozis olarak sonuçlandırdı. Íkinci ameliyattan sonra hasta adjuvan radyoterapi aldı. Hastanın 2 yıllık takibinde radyonekroz dışında ek patoloji saptanmadı. Radyolojik çalışmalar fibromatozis tanısı konulmasında yetersiz olabiliyor; bu sebeple patolojik preparat detaylı olarak incelenmelidir. Spinal fibromatozis çok nadirdir ve hâlâ genel kabul görmüşs standart bir tedavisi yoktur. Ancak; en blok cerrahiden sonra adjuvan tedaviler gerekmektedir.

ANAHTAR SÖZCÜKLER: Fibromatozis, Lomber omurga, Radyoterapi, Cerrahi

\section{INTRODUCTION}

Fibromatosis is a benign lesion, which originates from proliferating fibroblasts. Although fibromatosis is known as a benign tumor, it is locally aggressive and invasive. Fibromatosis is predominantly seen in females and the most common site of the tumor is the abdominal wall. The incidence of fibromatosis is $2-4$ cases per million $(14,15)$ which reaches a peak between $3^{\text {rd }}$ and $4^{\text {th }}$ decades of life $(3,14,15)$. Besides the abdominal wall; head, neck and limb are the other common sites of origin. Since spinal presentation of the fibromatosis is very rare; case reports are the only source of clinical knowledge. Hitherto, 14 cases have been described in the English literature (Table I) (1, 4-11,13,17-19). Now, we add an aggressive spinal fibromatosis case of the oldest aged patient in the literature, with 2 years follow-up.

\section{CASE REPORT}

A 68-year-old female patient admitted to our outpatient clinic with low back pain and neurological claudication. In her history, sometimes the pain radiated from the lateral aspects of her legs to dorso-lateral aspects of her feet. In the physical examination she had no motor weakness. However, she had bilateral hypoesthesia in lateral aspects of her thighs. On lumbar spine magnetic resonance imaging (MRI), she had 
Table I: Spinal Fibromatosis Cases in the Literature

\begin{tabular}{|c|c|c|c|c|c|c|c|}
\hline Authors & \begin{tabular}{|c|} 
Patient age \\
(year)/gender
\end{tabular} & Presentation & Etiology & Tumor location & Treatment & $\begin{array}{l}\text { Follow up } \\
\text { (months) }\end{array}$ & Recurrence \\
\hline $\begin{array}{l}\text { Wyler and } \\
\text { Harris, } 1973 \\
\text { (19) }\end{array}$ & $39, F$ & Painful mass & Post-op & $\begin{array}{l}\text { Cervicothoracic } \\
\text { junction }\end{array}$ & $\begin{array}{l}\text { Marginal } \\
\text { resection }\end{array}$ & 10 & Yes \\
\hline $\begin{array}{l}\text { Friede and } \\
\text { Pollak, } 1979 \\
\text { (4) }\end{array}$ & $11, F$ & $\begin{array}{l}\text { Lower limb } \\
\text { paralysis }\end{array}$ & De novo & Thoracic & $\begin{array}{l}\text { Intra-lesional } \\
\text { resection }\end{array}$ & $N \backslash A$ & $N \backslash A$ \\
\hline $\begin{array}{l}\text { Oberthaler } \\
\text { and } \\
\text { Rhomberg, } \\
1988 \text { (13) }\end{array}$ & $21, M$ & Painless mass & Post-op & Thoracic & $\begin{array}{l}\text { Intra-lesional } \\
\text { resection and } \\
\text { radiotherapy }\end{array}$ & 36 & No \\
\hline $\begin{array}{l}\text { Kriss and } \\
\text { Warf, } 1994 \\
\text { (9) }\end{array}$ & 19 month, $\mathrm{F}$ & Painless mass & De novo & Cervical & $\begin{array}{l}\text { Marginal } \\
\text { resection }\end{array}$ & 17 & No \\
\hline $\begin{array}{l}\text { Ko et al. } \\
1996(8)\end{array}$ & $3, F$ & Painless mass & De novo & Thoracic & $\begin{array}{l}\text { En bloc } \\
\text { resection }\end{array}$ & $N \backslash A$ & $N \backslash A$ \\
\hline $\begin{array}{l}\text { Maurer et al. } \\
1996(11)\end{array}$ & $18, F$ & Painless mass & Post-op & Lumbar & $\begin{array}{l}\text { Intra-lesional } \\
\text { resection }\end{array}$ & 6 & Yes \\
\hline $\begin{array}{l}\text { Lynch et al. } \\
1999 \text { (10) }\end{array}$ & $49, F$ & Painful mass & Post-op & Thoracic & $\begin{array}{l}\text { En bloc } \\
\text { resection }\end{array}$ & $N \backslash A$ & $N \backslash A$ \\
\hline $\begin{array}{l}\text { Shindle } \\
\text { et al. } 2002 \\
\text { (18) }\end{array}$ & $12, F$ & $\begin{array}{l}\text { Scoliosis and } \\
\text { lower limb } \\
\text { paralysis }\end{array}$ & De novo & Thoracic & $\begin{array}{l}\text { Intra-lesional } \\
\text { resection and } \\
\text { radiotherapy }\end{array}$ & 108 & No \\
\hline $\begin{array}{l}\text { Guzey et al. } \\
2006(6)\end{array}$ & $50, F$ & Painful mass & Post-op & $\begin{array}{l}\text { Thoracolumbar } \\
\text { junction }\end{array}$ & $\begin{array}{l}\text { En bloc } \\
\text { resection }\end{array}$ & 14 & No \\
\hline $\begin{array}{l}\text { Hara et al. } \\
2007 \text { (7) }\end{array}$ & $50, M$ & Shoulder pain & De novo & Thoracic & $\begin{array}{l}\text { Chemotherapy } \\
\text { and } \\
\text { radiotherapy }\end{array}$ & 12 & No \\
\hline $\begin{array}{l}\text { Chung et al. } \\
2010(1)\end{array}$ & $14, M$ & Asymptomatic & $\begin{array}{l}\text { Gardner } \\
\text { syndrome }\end{array}$ & Cervical & $\begin{array}{l}\text { Marginal } \\
\text { resection }\end{array}$ & 12 & No \\
\hline \multirow[t]{2}{*}{$\begin{array}{l}\text { Shakur et al. } \\
2013(17)\end{array}$} & $45, F$ & $\begin{array}{l}\text { Neck pain, } \\
\text { paresthesia }\end{array}$ & Recurrence & $\begin{array}{l}\text { Cervicothoracic } \\
\text { junction }\end{array}$ & $\begin{array}{l}\text { Intra-lesional } \\
\text { resection }\end{array}$ & 40 & No \\
\hline & $38, F$ & $\begin{array}{l}\text { Mild-back pain, } \\
\text { paresthesia }\end{array}$ & Recurrence & Thoracic & $\begin{array}{l}\text { En bloc } \\
\text { resection and } \\
\text { chemotherapy }\end{array}$ & 10 & No \\
\hline $\begin{array}{l}\text { Furlan et al. } \\
2013(5)\end{array}$ & $41, F$ & Low back pain & De novo & Lumbar & $\begin{array}{l}\text { Fine needle } \\
\text { aspiration }\end{array}$ & $N \backslash A$ & $N \backslash A$ \\
\hline Present case & $63, F$ & Low back pain & De novo & Lumbar & $\begin{array}{l}\text { Intra-lesional\& } \\
\text { en block } \\
\text { resection, } \\
\text { radiotherapy }\end{array}$ & 24 & Yes \\
\hline
\end{tabular}

Abbreviation: N\A: Not available. 
spinal canal stenosis between L2-L3 and L3-L4 disc levels and intervertebral disc herniations at L2-L3 and L4- L5 levels (Figure 1). Interestingly, we noticed an ill-defined mass with heterogenously high signal intensity in her left longissimus muscle. After the administration of intravenous contrast, the mass enhanced heterogeneously. An open biopsy was done to achieve the diagnosis (Figures 2A, B). The mass was hard and whitish in color. Frozen section result was indecisive about malignancy. Thus, we did our best to resect the entire mass. After this uneventful surgery, she recovered well. Pathological evaluation revealed that this was a spindle cell lesion, which was rich in collagen and fibrous stroma. The tumor cells were not pleomorphic or atypical. Mitotic figures were rare (equal to or less than 1 mitosis per 50 high power field) (Figures $3 \mathrm{~A}$, B). Immunohistochemical analysis showed that the tumor cells were focally positive for b-catenin, desmin and smooth muscle actin (SMA). Ki-67 proliferation index was lower than $1 \%$. We scheduled management of her lumbar spinal canal stenosis for a later date. She readmitted to our clinic with a growing mass over the site of her previous surgery, 6 months after the primary surgery. On physical examination, the mass was dark red-colored, immobile and painless. The skin over the mass was intact and no other lesion was extruding out of the incision line. On the new MRI, we observed that the previous lesion recurred in the previous site with a more aggressive clinic (Figure $2 \mathrm{C}$ ). To detect probable metastases a whole body check-up was ordered. She had no metastases. In the second surgery, we resected the entire mass and reconstructed with muscle flap. The macroscopic appearance of the mass was identical with the appearance of the previous mass. This time the frozen section revealed the mass as a lowgrade soft tissue malignancy. On the permanent pathologic examination, the mass was diagnosed as desmoid type fibromatosis. We consulted radiation oncologists and medical oncologists about her treatment. She was recommended to have radiotherapy, right after the wound healing. After the radiotherapy, she has been followed-up for 2 years. The mass never recurred. However, she had benign fluid collections. The fluid collection recurred a couple of times after less-invasive techniques. Finally, we resected the mass, which contained fluid (Figures 2D-F). The mass was hard. Pathologic evaluation revealed that the hard mass was a radionecrotic soft tissue

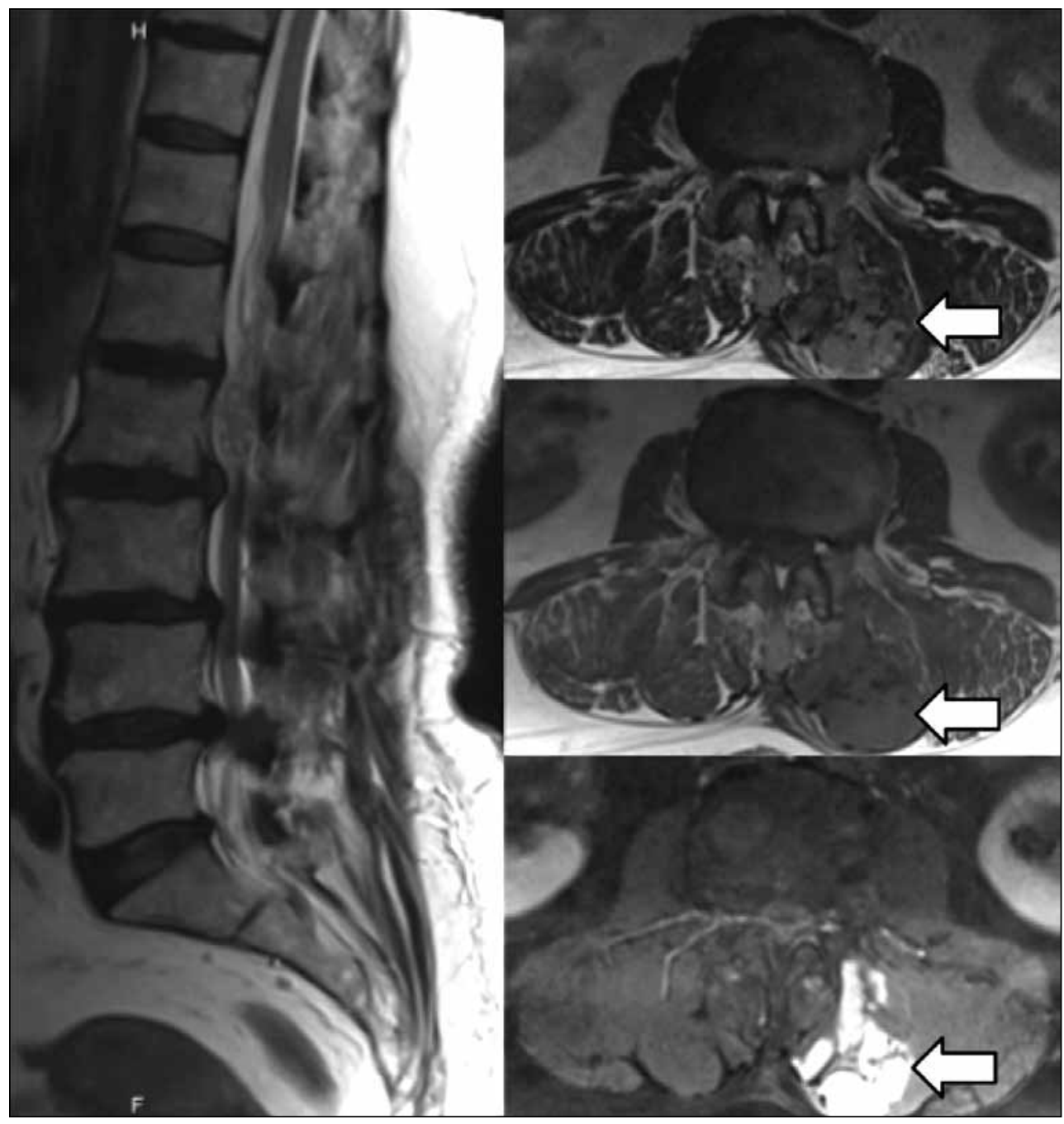

Figure 1: Preoperative lumbar MRI showing spinal stenosis between L2-L4 segments and heterogeneously enhanced lesion (white arrows) in paravertebral location at L4-L5 segments. 
mass. Six months after the last surgery, she was still well and the surgical site was free of recurrence.

\section{DISCUSSION}

Fibromatosis or desmoid tumor is a benign lesion, which originates from proliferating fibroblasts in a collagen background (6). McFarlane first described "desmoid tumor" in 1832, and Muller used "desmoid tumor" term in 1838, to describe the firm consistency of the tumor (6). The causes of fibromatosis are still unknown. However, some predisposing factors such as previous operation, familial or endocrinological diseases have been described in the literature (6). Although it is a benign tumor, it is locally aggressive and invasive. Recurrence of fibromatosis has been reported such high

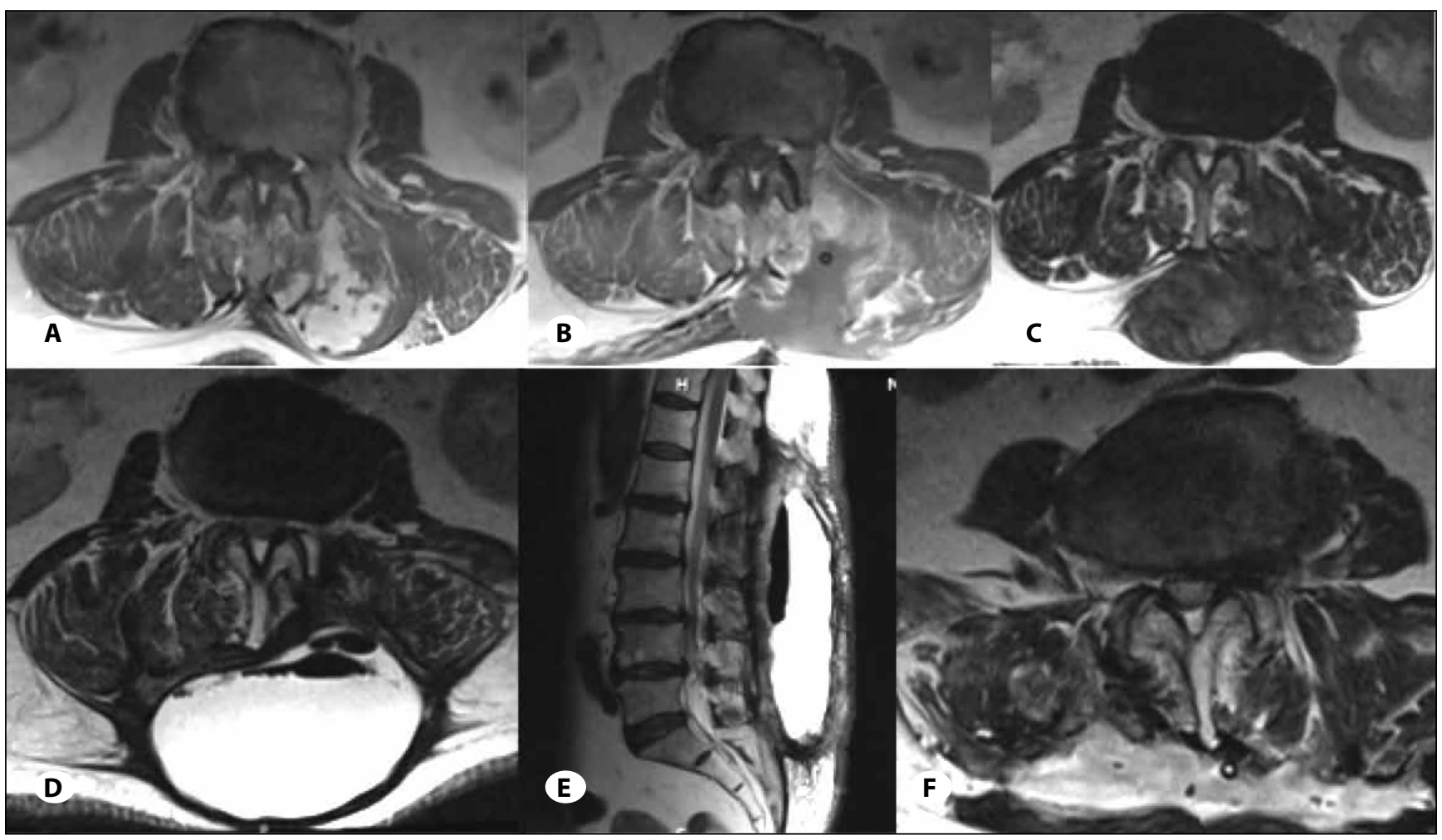

Figure 2: Preoperative contrast enhanced T1-weighted axial image shows a heterogenous lesion in left longissimus muscle (A). Immediate postoperative contrast enhanced T1-weighted axial MRI shows some residual lesion (B). Six-months after the primary surgery, the lesion locally recurred (C). In the second surgery, we made en bloc resection. She took adjuvant radiotherapy. However, benign fluid collections have occurred $(\mathbf{D}, \mathbf{E})$. After a couple of fluid drainage, we resected fluid filled cyst. MRI shows the lesion has been totally resected (F).
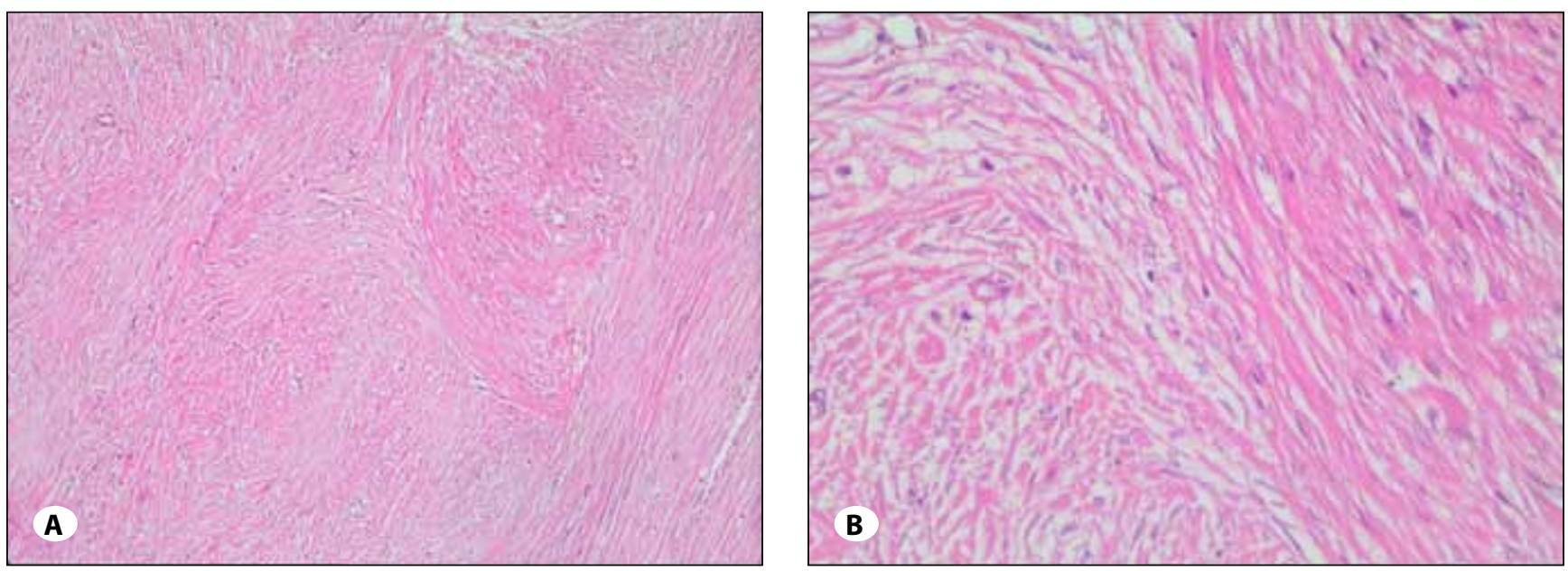

Figure 3: Tumor is hypocellular and rich in collagen and fibrous stroma (A-HE, 4x). Tumor cells are spindle shaped and plump; have small pinpoint nuclei. There is no atypia (B-HE, 200x). 
as $50 \%(2,16)$. Fibromatosis is most commonly seen in the abdominal wall. Fibromatosis is also seen in head, neck and limbs. Spinal presentation of the fibromatosis is very rare, that only 14 cases with spinal fibromatosis have been presented in the literature (Table I) (1, 4-11, 13, 17-19). Sex hormones were claimed to affect fibromatosis, since both cases with abdominal wall fibromatosis and spinal fibromatosis are more common in females $(6,17)$. However, our patient was in postmenopausal period.

Ages of reported spinal fibromatosis cases ranged from 19 months to 50 years $(1,4-11,13,17-19)$. Our patient has been the oldest person with spinal fibromatosis, in the literature. Presenting symptoms are pain with or without mass, paresthesia and limb paralysis (4, 6-11,13,17-19). On the other hand, spinal fibromatosis can be totally asymptomatic (1). It was shown to be related with a syndrome only in one case (1). Thoracic spine is the most common site of origin for spinal fibromatosis cases $(4,7,8,10,13,17,18)$. Our patient had fibromatosis in lumbar spine region, which has been the third presentation of this region with fibromatosis, in the literature $(5,11)$. Spinal fibromatosis can be both de novo in origin and secondary to previous surgeries (4-11, 13, 17-19). In our case, although the first appearance was de novo, second occurrence may be due to previous surgery.

Differential diagnoses include fibrous meningioma, reactive fibrosis, fibroma, fibrosarcoma, solitary fibrous tumor, fibrous dysplasia and metastasis $(4,6)$. It is very hard to achieve the accurate diagnosis, even with radiological and histopathological evaluation (17). In our case, we also had difficulty in achieving the accurate diagnosis.

Radiological work-up is usually insufficient to diagnose the mass accurately, prior to the surgery. Even pathological evaluation could miss the diagnosis, if it is not done thoroughly with enough immunohistochemical analysis. However, MRI is the best tool to see borders of the tumor and the relation between the tumor and surrounding soft tissue or neuronal elements. Magnetic resonance imaging of our patient incidentally detected the lesion during work-up for lumbar fusion surgery.

There are only 15 cases in the literature; so making a final comment upon treatment for spinal fibromatosis cases is very difficult. Although en bloc resection is beneficial for these benign but locally aggressive tumors, combined adjuvant chemotherapy or radiotherapy are recommended relying upon experiences with conventional large fibromatosis series in the literature (17). Local control rate after radiotherapy is 70 to $80 \%$ (12). In our case, tumor recurrence ceased only after adjuvant radiotherapy treatment.

\section{CONCLUSION}

Fibromatosis is a benign tumor with locally aggressive nature. Radiological work-up is usually insufficient and whole pathological specimen should be carefully evaluated for accurate diagnosis. Spinal fibromatosis is very rare and there is no consensus about treatment methods. However, adjuvant therapies are necessary after en bloc resection.

\section{REFERENCES}

1. Chung KH, Charlton A, Arbuckle S, Chaseling R, Owler BK: Metachronous multifocal desmoid-type fibromatoses along the neuraxis with adenomatous polyposis syndrome. J Neurosurg Pediatr 6:372-376, 2010

2. Dalen BP, Bergh PM, Gunterberg BU: Desmoid tumors: A clinical review of 30 patients with more than 20 years' followup. Acta Orthop Scand 74:455-459, 2003

3. Easter DW, Halasz NA: Recent trends in the management of desmoid tumors. Summary of 19 cases and review of the literature. Ann Surg 210:765-769, 1989

4. Friede RL, Pollak A: Neurosurgical desmoid tumors: Presentation of four cases with a review of the differential diagnoses. J Neurosurg 50:725-732, 1979

5. Furlan JC, Valiante T, Dickson B, KiehI TR: Paraspinal desmoidtype fibromatosis as a cause of low back pain. Spine J 13:19581959, 2013

6. Guzey FK, Emel E, Bas NS, Ozkan N, Turgut H, Sel B: Aggressive postoperative lumbar fibromatosis after the placement of instrumentation for treatment of spondylolisthesis. Case report. J Neurosurg Spine 4:338-341, 2006

7. Hara $R$, Matsuguma $H$, Suzuki $H$, Ishikawa $Y$, Nakahara R, Yamaguchi T, et al: Desmoid tumor presenting as a superior sulcus tumor: A unique bone change in the vertebral body. Ann Thorac Surg 84:1752-1754, 2007

8. Ko SF, Ng SH, Hsiao CC, Hsieh CS, Lin JW, Huang CC, et al: Juvenile fibromatosis of the posterior mediastinum with intraspinal extension. AJNR Am J Neuroradiol 17:522-524, 1996

9. Kriss TC, Warf BC: Cervical paraspinous desmoid tumor in a child: Case report. Neurosurgery 35:956-959; discussion 959, 1994

10. Lynch JJ, Parvizi J, Scheithauer BW, Krauss WE: Development of postoperative fibromatosis after resection of an intraspinal meningioma. Case report. J Neurosurg 90:121-124, 1999

11. Maurer F, Horst F, Pfannenberg C, Wehrmann M: Multifocal extra-abdominal desmoid tumor--diagnostic and therapeutic problems. Arch Orthop Trauma Surg 115:359-362, 1996

12. Nuyttens JJ, Rust PF, Thomas CR Jr, Turrisi AT 3rd: Surgery versus radiation therapy for patients with aggressive fibromatosis or desmoid tumors: A comparative review of 22 articles. Cancer 88:1517-1523, 2000

13. Oberthaler W, Rhomberg W: Aggressive fibromatosis. A rare cause for lumbar bulging. Arch Orthop Trauma Surg 107: 388-390, 1988

14. Reitamo JJ, Hayry P, Nykyri E, Saxen E: The desmoid tumor. I. Incidence, sex-, age- and anatomical distribution in the Finnish population. Am J Clin Pathol 77:665-673, 1982

15. Reitamo JJ, Scheinin TM, Hayry P: The desmoid syndrome. New aspects in the cause, pathogenesis and treatment of the desmoid tumor. Am J Surg 151:230-237, 1986 
16. Rock MG, Pritchard DJ, Reiman HM, Soule EH, Brewster RC: Extra-abdominal desmoid tumors. J Bone Joint Surg Am 66:1369-1374, 1984

17. Shakur SF, Takagi I, Jacobsohn JA, Golden BM, Karahalios DG: Spinal fibromatosis: A report of two cases and review of the literature. Spine J 13:e1-6, 2013
18. Shindle MK, Khanna AJ, McCarthy EF, O'Neill PJ, Sponseller PD: Desmoid tumor of the spinal canal causing scoliosis and paralysis. Spine (Phila Pa 1976) 27:E304-307, 2002

19. Wyler AR, Harris $A B$ : Recurrent desmoid tumor following cervical laminectomy. Case report. J Neurosurg 39:114-116, 1973 